\title{
Ammonium sulfate rates affect the Structural Characteristics, Biomass and Crude Protein of BRS Tamani Grass
}

\author{
Victor Luan da Silva de Abreu \\ Fundação Universidade Federal de Mato Grosso do Sul, Brazil \\ ORCID: https://orcid.org/0000-0003-3703-7678 \\ E-mail: viictorabreu@gmail.com
}

Henrique De Oliveira Golin

Fundação Universidade Federal de Mato Grosso do Sul, Brazil

ORCID: https://orcid.org/0000-0001-7909-7172

E-mail: henriquegolin1@gmail.com

Rafael Padilha de Rezende

Fundação Universidade Federal de Mato Grosso do Sul, Brazil

ORCID: https://orcid.org/0000-0002-1468-5835

E-mail: rafinharezende7@gmail.com

Patrick Bezerra Fernandes

Fundação Universidade Federal de Mato Grosso do Sul, Brazil

ORCID: https://orcid.org/0000-0003-2368-943X

E-mail: zoo.patrick@hotmail.com

Gustavo de Faria Theodoro

Fundação Universidade Federal de Mato Grosso do Sul, Brazil

ORCID: https://orcid.org/0000-0002-1230-2124 
E-mail: gustavo.theodoro@ufms.br

\author{
Gumercindo Loriano Franco \\ Fundação Universidade Federal de Mato Grosso do Sul, Brazil \\ ORCID: https://orcid.org/0000-0002-9868-0256 \\ E-mail: gumercindo.franco@ufms.br \\ Gelson dos Santos Difante \\ Fundação Universidade Federal de Mato Grosso do Sul, Brazil \\ ORCID: http://orcid.org/0000-0001-6610-8952 \\ E-mail: gelson.difante@ufms.br
}

\author{
Received: July 10, $2020 \quad$ Accepted: Aug. 6, $2020 \quad$ Published: Sep. 27, 2020 \\ doi:10.5296/jas.v8i4.17336 \\ URL: https://doi.org/10.5296/jas.v8i4.17336
}

\begin{abstract}
The mineral nutrition of forage species is essential for the maintenance of sustainable livestock systems, since it can increase animal productivity per area. Panicum maximum is considered nutritionally demanding. However, the behavior of modern cultivars under nitrogen fertilization is unknown. The objective of this study was to evaluate the effects of increasing doses of nitrogen $(\mathrm{N})$ on the structural characteristics, forage biomass, and crude protein $(\mathrm{CP})$ of cultivar BRS Tamani. The experimental design was randomized blocks, and the treatments consisted of six $\mathrm{N}$ doses $\left(0,62.5,125,250,375\right.$, and $\left.500 \mathrm{~N} \mathrm{mg} \cdot \mathrm{dm}^{-3}\right)$ using ammonium sulfate (AS) fertilizer, divided into three coverage applications under greenhouse conditions. Three cuts were made from all treatments, separated by an interval of 30 days. The interval between cuts was considered a split-plot effect. There was no interaction effect between the cuts and AS doses for the number of leaves tiller ${ }^{-1}$ or crude protein. However, there was an interaction effect for the leaf length, number of tillers, and biomass. The use of doses between 280 and $380 \mathrm{mg} \mathrm{N} \cdot \mathrm{dm}^{-3}$ influenced the structural characteristics of the canopy and biomass of 'BRS Tamani' grass. The highest $\mathrm{CP}$ value was recorded in the first cut.
\end{abstract}

Keywords: fertilization, morphology, sustainability, yield

\title{
1. Introduction
}

Nitrogen $(\mathrm{N})$ is one of the nutrients that most influences the phenotypic plasticity of grass tillers. An adequate supply of $\mathrm{N}$ boosts the photosynthetic processes for the transformation 
and fixation of atmospheric carbon into biomass (Li et al., 2019), in addition to increasing the deposition of crude protein (CP) in the aerial part of the canopy, improving the food value of the forage (Paciullo et al., 2016; Gurgel et al., 2020).

However, due to the diversity of grasses that exist in tropical climate environments, each genus and cultivar has different management requirements (e.g., fertilization and defoliation strategies), due to the variations presented in the tissue flow and biomass production (Oliveira et al., 2020; Veras et al., 2020a; 2020b).

Panicum maximum has a high rate of organogenesis, organ expansion, tissue flow, and forage accumulation in relation to other grasses from tropical climates (Rodrigues et al., 2012; Gomide et al., 2019). Therefore, P. maximum exhibits a greater demand for mineral nutrition to express the maximum yield potential (Cabral et al., 2020).

Furthermore, to ensure that the biomass production presents satisfactory agronomic values, it is necessary to consider the effects of the $\mathrm{N}$ source that will be used. Costa et al. (2010) stated that, due to the lower $\mathrm{N}$ losses through volatilization, the use of ammonium sulfate $(300 \mathrm{~kg}$ of $\mathrm{N} \mathrm{ha}^{-1}$ ) results in greater increases in biomass production compared to other $\mathrm{N}$ sources.

On the other hand, the current agricultural systems aim for primary productivity in a sustainable manner, i.e., proposing alternative management strategies that reduce the input of chemical fertilizers in the environment, aiming to promote a balance between environmental factors and economic gains (Epifanio et al., 2019; Fernandes et al., 2020).

A possible alternative management strategy is the use of moderate doses of $\mathrm{N}$ (e.g., 100 to $200 \mathrm{~kg}$ of $\mathrm{N} \mathrm{ha}^{-1}$ ). By adopting this fertilization strategy in tropical climate pastures, it is possible to achieve a balance in the leaf area dynamics, thus maximizing the production of forage biomass, as recorded by Menezes et al. (2019) and Oliveira-Neto et al. (2020) in areas managed under lenient defoliation.

Therefore, the tested hypothesis was whether moderate doses of ammonium sulfate promote positive effects on the biomass and deposition of CP in BRS Tamani grass. Accordingly, the objective of this study was to verify the effects of increasing doses of ammonium sulfate on the structural characteristics, forage biomass, and CP of Panicum maximum cv. BRS Tamani.

\section{Method}

The experiment was conducted at the Faculdade de Medicina Veterinária e Zootecnia, Universidade Federal de Mato Grosso do Sul, in the city of Campo Grande, State of Mato Grosso do Sul (MS), Brazil, under greenhouse conditions from November 2017 to March 2018.

A Red Latosol of medium texture was employed (sand: $680 \mathrm{~g} \mathrm{~kg}^{-1}$, silt: $100 \mathrm{~g} \mathrm{~kg}^{-1}$, clay: 220 $\mathrm{g} \mathrm{kg}^{-1}$ ), which had been collected from the 0-20 cm layer in Terenos city, MS. The soil had the following chemical characteristics: $\mathrm{pH}$ (water) 5.82, $\mathrm{P}\left(\mathrm{mg} \cdot \mathrm{dm}^{-3}\right) 2.18, \mathrm{MO}\left(\mathrm{g}^{-\mathrm{dm}^{-3}}\right)$ 9.66, $\mathrm{K}\left(\mathrm{cmol} \cdot \mathrm{dm}^{-3}\right)$ 0.08, $\mathrm{Ca}\left(\mathrm{cmol} \cdot \mathrm{dm}^{-3}\right) 1.15, \mathrm{Mg}\left(\mathrm{cmol} \cdot \mathrm{dm}^{-3}\right)$ 0.6, $\mathrm{Ca}+\mathrm{Mg}\left(\mathrm{cmol} \cdot \mathrm{dm}^{-3}\right) 1.75, \mathrm{Al}$ $\left(\mathrm{cmol} \cdot \mathrm{dm}^{-3}\right)$ 0, H $\left(\mathrm{cmol} \cdot \mathrm{dm}^{-3}\right) 1.45, \mathrm{Al}+\mathrm{H}\left(\mathrm{cmol} \cdot \mathrm{dm}^{-3}\right) 1.45, \mathrm{~S}\left(\mathrm{cmol} \cdot \mathrm{dm}^{-3}\right) 1.83, \mathrm{~T}$ $\left(\mathrm{cmol} \cdot \mathrm{dm}^{-3}\right) 3.28$, and $\mathrm{V}(\%) 55.79$. 
The soil was sieved, and $8 \mathrm{dm}^{3}$ was deposited in each pot. The fertilizer base was used in accordance with the results of the soil chemical analysis, applying $10 \mathrm{~g}$ of simple superphosphate $\left(18 \% \mathrm{P}_{2} \mathrm{O}_{5}\right)$ and $1.05 \mathrm{~g}$ of potassium chloride $\left(58 \% \mathrm{~K}_{2} \mathrm{O}\right)$. Seeds were sown directly into the pots on November 21, 2017, at a rate of 30 seeds per pot. On the tenth day (12/01/17), thinning was conducted to select the five seedlings exhibiting the most similarities. The plants were irrigated according to Gomide \& Gomide (2000).

The experimental design was in randomized blocks. The treatments consisted of six $\mathrm{N}$ doses $\left(0,62.5,125,250,375\right.$, and $\left.500 \mathrm{~N} \mathrm{mg} \cdot \mathrm{dm}^{-3}\right)$ using ammonium sulfate fertilizer $(20 \% \mathrm{~N}$; $22 \%$ S) (Costa et al., 2010). For each treatment, the $\mathrm{N}$ doses were divided into three coverage applications: 12/21/17 (first cut), 01/22/18 (second cut), and 02/21/18 (third cut), which was the same day that the standardization cut was performed (thirty days after sowing). The cuts were separated by an interval of 30 days each. The interval between cuts was considered a split-plot effect.

The three cuts were made at a height of $15 \mathrm{~cm}$. Simultaneously, the following evaluations were made: medium leaf length $(\mathrm{cm})$, number of leaves tiller ${ }^{-1}$, number of tillers pot $^{-1}$, and biomass $\left(\mathrm{g} \mathrm{pot}^{-1}\right)$. To measure the production of dry matter $(\mathrm{DM})$, samples were taken from each pot, with all plants cut at a height of $15 \mathrm{~cm}$. These samples were weighed and transferred into paper bags. Subsequently, the samples were accommodated in greenhouses with forced ventilation at a temperature of $55^{\circ} \mathrm{C}$, until they reached a constant weight. Then, the samples were ground to a grain size of $2 \mathrm{~mm}$ and relocated to a greenhouse at $105^{\circ} \mathrm{C}$, until a constant weight was reached. During the grinding process, it was possible to evaluate the crude protein quantification by means of chemical analysis, following the method described by AOAC (1995).

The data concerning the structural characteristics, biomass, and $\mathrm{CP}$ were analyzed following a randomized block design in a split-plot arrangement:

$$
\text { Yijk }=\mu+\mathrm{Ni}+\mathrm{Bk}+\mathrm{eik}+\mathrm{Cj}+(\mathrm{NCij})+\text { eijk }
$$

where Yijk: observed value; $\mu$ : general constant; Ni: effect of ammonium sulfate doses $(0$,

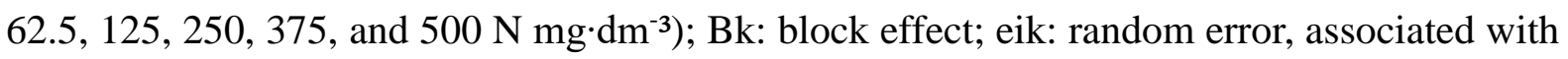
each observation i and $\mathrm{k}$; Cj: split-plot effect $\left(1^{\circ}\right.$ : first cut, $2^{\circ}$ : second cut, and $3^{\circ}$ : third cut); NCij: effect of the interaction between the ammonium sulfate doses and split-plot arrangement; and eij: random error, associated with each observation $\mathrm{i}$ and $\mathrm{j}$. When applicable, a Tukey's means comparison test was performed at a significance level of 5\%. In addition, the $\mathrm{N}$ doses were subjected to first- $(\mathrm{Yij}=\mathrm{a}+\mathrm{bN}+$ eij $)$ and second-degree $\left(\mathrm{Yij}=\mathrm{a}+\mathrm{bN}+\mathrm{cN}^{2}+\right.$ eij) regression analysis, choosing the model with a significant effect and the highest coefficient of determination $\left(\mathrm{R}^{2}\right)$. For the analyses, we used the ExpDes package (Ferreira et al., 2014) of software $\mathrm{R}$ version 3.6.1.

\section{Results}

There was no interaction effect between the cuts and doses of ammonium sulfate $(P=0.115)$ for the number of leaves tiller ${ }^{-1}$. Proportionality was observed between the $\mathrm{N}$ doses $(P=$ 0.356 ), with an estimated mean value of 2.2 leaves tiller $^{-1}$. Between the cuts, variations were 
present $(P<0.001)$, in which the second cut promoted the largest number of leaves tiller ${ }^{-1}$ (Figure 1). An interaction effect was observed between the ammonium sulfate doses and cuts for leaf length $(P=0.005)$, number of tillers $(P<0.001)$, and biomass $(P<0.001)$ (Table 1$)$.

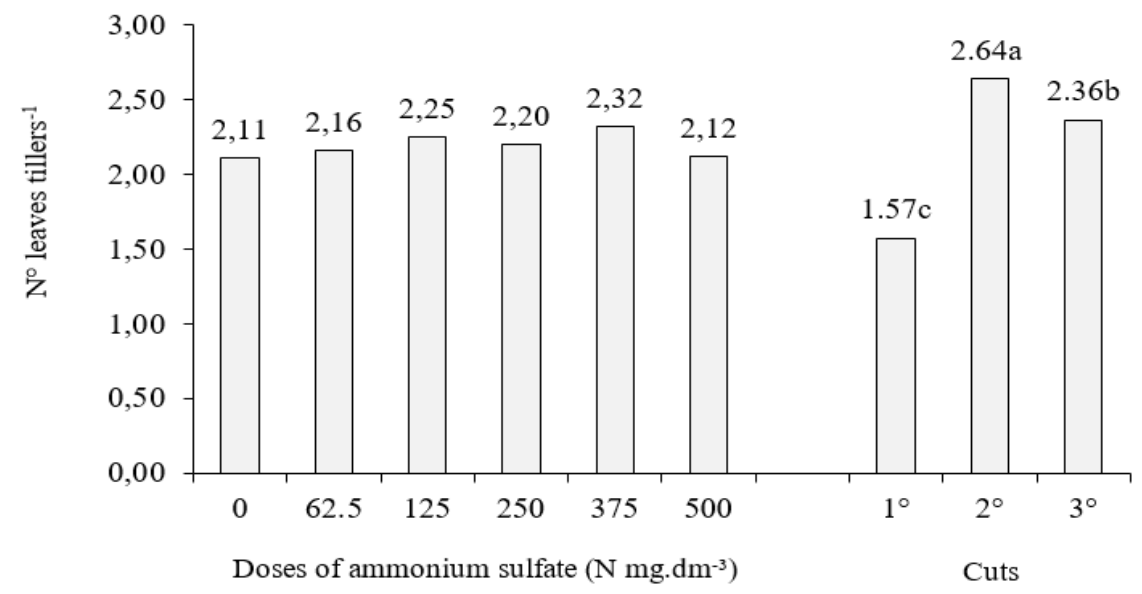

Figure 1. Number of leaves tiller ${ }^{-1}$ as a function of the ammonium sulfate doses and cuts of Panicum maximum cv. BRS Tamani. Different lower-case letters between the columns indicate a statistical difference according to the Tukey's test at a 5\% probability

Table 1. Structural characteristics and biomass as a function of the ammonium sulfate doses and cuts of Panicum maximum cv. BRS Tamani

\begin{tabular}{|c|c|c|c|c|c|c|c|c|}
\hline \multirow[b]{2}{*}{ Cut } & \multicolumn{6}{|c|}{ Doses of ammonium sulfate $\left(\mathrm{N} \mathrm{mg.dm}{ }^{-3}\right)$} & \multirow[b]{2}{*}{ Equation } & \multirow[b]{2}{*}{$\mathrm{R}^{2}$} \\
\hline & 0 & 62,5 & 125 & 250 & 375 & 500 & & \\
\hline \multicolumn{9}{|c|}{ Leaf length $(\mathrm{cm})$} \\
\hline $\mathrm{C} 1$ & $12^{\mathrm{b}}$ & $17^{\mathrm{b}}$ & $18^{\mathrm{b}}$ & $18^{\mathrm{c}}$ & $18^{\mathrm{c}}$ & $18^{\mathrm{c}}$ & NS & - \\
\hline $\mathrm{C} 2$ & $22^{\mathrm{a}}$ & $37^{\mathrm{a}}$ & $38^{\mathrm{a}}$ & $44^{\mathrm{a}}$ & $43^{\mathrm{a}}$ & $45^{\mathrm{a}}$ & $\mathrm{y}=25.75+0.113 \mathrm{~N}-0.0002 \mathrm{~N}^{2}$ & 0.863 \\
\hline $\mathrm{C} 3$ & $21^{\mathrm{a}}$ & $28^{\mathrm{c}}$ & $24^{\mathrm{b}}$ & $26^{\mathrm{b}}$ & $30^{\mathrm{b}}$ & $28^{\mathrm{b}}$ & NS & - \\
\hline SEM & \multicolumn{8}{|c|}{1.30} \\
\hline \multicolumn{9}{|c|}{ Number of tillers pot ${ }^{-1}$} \\
\hline $\mathrm{C} 1$ & $3^{\mathrm{a}}$ & $7^{\mathrm{a}}$ & $7^{\mathrm{a}}$ & $10^{\mathrm{a}}$ & $9^{a}$ & $9^{a}$ & $\mathrm{y}=3.57+0.036 \mathrm{~N}-0.0001 \mathrm{~N}^{2}$ & 0.919 \\
\hline $\mathrm{C} 2$ & $2^{\mathrm{a}}$ & $3^{\mathrm{b}}$ & $4^{b}$ & $5^{\mathrm{b}}$ & $5^{\mathrm{b}}$ & $6^{\mathrm{b}}$ & $\mathrm{y}=2.00+0.017 \mathrm{~N}-0.00002 \mathrm{~N}^{2}$ & 0.975 \\
\hline $\mathrm{C} 3$ & $2^{\mathrm{a}}$ & $5^{\mathrm{ab}}$ & $7^{\mathrm{a}}$ & $9^{\mathrm{a}}$ & $8^{\mathrm{a}}$ & $4^{b}$ & $\mathrm{y}=1.61+0.058 \mathrm{~N}-0.0001 \mathrm{~N}^{2}$ & 0.997 \\
\hline SEM & & \multicolumn{7}{|c|}{0.341} \\
\hline \multicolumn{9}{|c|}{ Biomass $\left(\mathrm{g} \mathrm{pot}^{-1}\right)$} \\
\hline $\mathrm{C} 1$ & $2.23^{\mathrm{a}}$ & $3.37^{\mathrm{b}}$ & $12.97^{\mathrm{b}}$ & $15.02^{\mathrm{b}}$ & $16.54^{\mathrm{b}}$ & $14.72^{\mathrm{b}}$ & $\mathrm{y}=1.35+0.086 \mathrm{~N}-0.0001 \mathrm{~N}^{2}$ & 0.915 \\
\hline $\mathrm{C} 2$ & $3.13^{\mathrm{a}}$ & $10.32^{\mathrm{a}}$ & $25.36^{\mathrm{a}}$ & $31.24^{\mathrm{a}}$ & $30.65^{\mathrm{a}}$ & $24.73^{\mathrm{a}}$ & $\mathrm{y}=2.74+0.187 \mathrm{~N}-0.0003 \mathrm{~N}^{2}$ & 0.960 \\
\hline $\mathrm{C} 3$ & $4.78^{\mathrm{a}}$ & $3.09^{\mathrm{b}}$ & $13.08^{b}$ & $15.56^{\mathrm{b}}$ & $18.60^{\mathrm{b}}$ & $16.50^{\mathrm{b}}$ & $\mathrm{y}=2.81+0.076 \mathrm{~N}-0.0001 \mathrm{~N}^{2}$ & 0.872 \\
\hline SEM & & & 1. & 10 & & & & \\
\hline
\end{tabular}

$\mathrm{C} 1$ : first cut, $\mathrm{C} 2$ : second cut, $\mathrm{C} 3$ : third cut, $\mathrm{R}^{2}$ : coefficient of determination, and SEM: standard error of the mean. Different lower-case letters in a column indicate a statistical difference according to the Tukey's test at a 5\% probability. NS: not significant for first- and second-degree equations. 
The leaf length between the ammonium sulfate doses did not fluctuate in the first $(P=0.454)$ or third cuts $(P=0.093)$, making it possible to estimate a mean value of 17 and $26 \mathrm{~cm}$, respectively. On the other hand, the second cut, in relation to the other evaluations, presented the highest leaf laminar length values. In addition, the second cut was influenced by the $\mathrm{N}$ doses and presented the best fit to the second-degree equation $(P<000.1)$. Using a $\mathrm{N}$ dose of $283 \mathrm{mg} \cdot \mathrm{dm}^{-3}$ resulted in a mean leaf length of $42 \mathrm{~cm}$ (Table 1).

For the number of tillers pot $^{-1}$, proportionality between the cuttings was observed when $\mathrm{N}$ was not supplied $(P=0.355)$. In the other experimental scenarios, ammonium sulfate influenced the number of tillers $(P<0.001)$. Therefore, due to the effects of $\mathrm{N}$ fertilization, each cut fit to the second-degree equation $(P<0.001)$, with high determination coefficients. In the first cut, the $180 \mathrm{mg} \cdot \mathrm{dm}^{-3}$ dose resulted in the initial generation of 7 tillers $\operatorname{pot}^{-1}$. In the second cut, there was a reduction in the tiller community (6 tillers pot $\left.^{-1}\right)$, while a greater demand for $\mathrm{N}$ was noted $\left(425 \mathrm{mg} \cdot \mathrm{dm}^{-3}\right)$. In the third cut, there was a reduction in the $\mathrm{N}$ demand $\left(290 \mathrm{mg} \cdot \mathrm{dm}^{-3}\right)$, but a $40 \%$ increase in the tiller population (Table 1$)$.

Regarding the forage biomass, the $\mathrm{N}$ supply impacted the variations between the cuts $(P<$ 0.001 ). In the first cut, the $430 \mathrm{mg} \cdot \mathrm{dm}^{3}$ dose resulted in an estimate of $20 \mathrm{~g}$ of biomass pot $^{-1}$. In the second cut, despite the reduction in the number of tillers, there was an increase in the biomass value ( $32 \mathrm{~g} \mathrm{pot}^{-1}$ ) and decrease in the $\mathrm{N}$ demand in relation to the first cut (312 $\left.\mathrm{mg} \cdot \mathrm{dm}^{-3}\right)$. In the third cut, the $380 \mathrm{mg} \cdot \mathrm{dm}^{-3}$ dose resulted in only $17 \mathrm{~g}$ of forage biomass pot $^{-1}$.

For the $\mathrm{CP}$, no interaction effect between the ammonium sulfate doses and cuts $(P=0.865)$ was observed. In addition, no fluctuations were observed regarding the ammonium sulfate doses $(P=0.944)$, with an estimated mean value of $14 \%$. Among the cuts, disproportionality was observed $(P<0.001)$, with the highest crude protein value being recorded in the first cut. For the second and third cuts, it is possible to estimate a mean crude protein value of $11 \%$ (Figure 2).

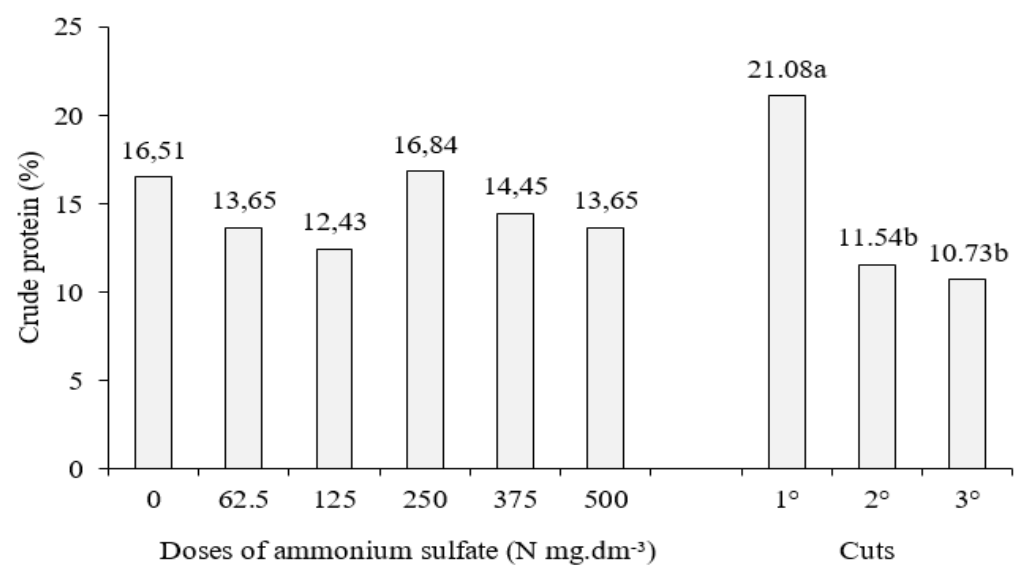

Figure 2. Proportion of $\mathrm{CP}$ as a function of the ammonium sulfate doses and cuts of Panicum maximum cv. BRS Tamani. Different lower-case letters between the columns indicate a statistical difference according to the Tukey's test at a 5\% probability 


\section{Discussion}

The lowest value regarding the number of leaves was observed in the first cut, which is related to the implantation of the forage canopy, as the grass is adapting to the adopted management. Therefore, in the next leaf area recovery cycle, the number of leaves per tiller will increase (Figure 1: $2^{\circ}$ cut and $3^{\circ}$ cut). Regarding the number of leaves per tiller recorded between doses, higher estimates as the $\mathrm{N}$ supply increases are unlikely, since the number of leaves is genetically predetermined (Lemaire et al., 2009). Therefore, it is expected that tillers have 2 to 3 leaves (Barbosa et al., 2011).

Despite the proportionality in the number of leaves, it is important to remember that the aerial part of the canopy is the main drain organ after defoliation. That is, due to the low photosynthetic capacity of the remaining leaf area, there is an increase in the remobilization of carbohydrates from the plant's reserves to tissue expansion (Da Silva et al., 2015). In addition, knowing that $\mathrm{N}$ synergistically enhances the cell multiplication process for the renewal and expansion of the leaf area, it is possible to deduce that an inadequate $\mathrm{N}$ supply after defoliation can reduce the primary production and longevity of the forage canopy (Gastal \& Lemaire, 2015).

During the recovery of the leaf area after the first defoliation, nitrogen fertilization (425 $\mathrm{mg} \cdot \mathrm{dm}^{-3}$ ) facilitated the tissue expansion process of the 'BRS Tamani' tillers, allowing an increase in the leaf area values. According to Gastal \& Lemaire (2015), this phenomenon prompts a reduction in the number of tillers with a higher specific weight $\left(\mathrm{g} \mathrm{DM} \mathrm{cm}^{-1}\right)$, that is, even at high dosages, less carbon and nitrogen are converted into biomass.

In the last cut, the increase in the tiller count of 'BRS Tamani' does not equate to an increase in the biomass. For tropical pastures, an increase in the number of tillers is generally related to the stress exerted by the effects of the intensity and frequency of defoliation on the forage canopy, leading to a change in the growth strategy of the tillers to efficiently enhance the leaf area recovery. This phenomenon is known as 'site filling', in which the leaf length of the tiller reduces (third cut; Table 1) and, as an alternative way of increasing the leaf area index in the forage canopy, the tiller community significantly increases (Barbosa et al., 2011; Martins et al., 2020; Veras et al., 2020a).

As it was not possible to observe a proportional increase in the forage biomass as the $\mathrm{N}$ supply increased, it was deduced that the use of high $\mathrm{N}$ doses is undesirable. Thus, moderate $\mathrm{N}$ doses (e.g., 280 and $380 \mathrm{mg} \cdot \mathrm{dm}^{-3}$ ) boost the tillering of 'BRS Tamani', ensuring primary production in a sustainable manner, which would mean a reduction in the investments into fertilizers.

The CP values for the aerial part of the 'BRS Tamani' cultivar are close to those considered adequate for Panicum maximum cultivars (Euclides et al., 2017; Alvarenga et al., 2020). Potentially, the influence of fertilization with other abiotic factors (e.g., hydrical stress; Oliveira et al., 2020), and the residual effects of different long-term doses, could impact the botanical composition of the forage canopy as well as the proportion of crude protein and other chemical components in plants. 


\section{Conclusion}

The use of moderate doses of ammonium sulfate as a nitrogen source, between 280 and 380 $\mathrm{mg} \cdot \mathrm{dm}^{-3}$, increases the tillering of 'BRS Tamani', guaranteeing primary production in a sustainable manner, which would mean a reduction in the investments into fertilizers.

\section{Acknowledgments}

This study was funded in part by the Coordenação de Aperfeiçoamento de Pessoal de Nível Superior - Brasil (CAPES) - Finance Code 001. The authors thank to Universidade Federal de Mato Grosso do Sul.

\section{References}

Alvarenga, C. A., Euclides, V. P., Montagner, D. B., Sbrissia, A. F., Barbosa, R. A., \& Araújo, A. R. (2020). Animal performance and sward characteristics of Mombaça guineagrass pastures subjected to two grazing frequencies. Tropical Grasslands-Forrajes Tropicales, 8(1), 1-10. https://doi.org/10.17138/tgft(8)1-10

AOAC (Association of Official Analytical Chemists). (1995). Agriculture chemicals; contaminants, drugs. Official methods of analysis of the Association of Official Analytical Chemists, 2-198.

Barbosa, R. A., Nascimento-Júnior, D. D., Vilela, H. H., Da Silva, S. C., Euclides, V. P. B., Sbrissia, A. F., \& Sousa, B. M. D. L. (2011). Morphogenic and structural characteristics of guinea grass pastures submitted to three frequencies and two defoliation severities. Revista Brasileira de Zootecnia, 40(5), 947-954. https://doi.org/10.1590/S1516-35982011000500002

Cabral, C. E. A., Cabral, C. H. A., Tesk, C. R. M., Mota, L. G., Groto, G. C., Motta, L. J. M., ... Santos A R. M. (2020). Nitrogen requirement of Brachiaria hybrid cv. Ipyporã. Boletim De Indústria Animal, 77, 1-10. https://doi.org/10.17523/bia.2020.v77.e1467

Costa, K. A. P., Faquin, V., \& Oliveira, I. P. (2010). Doses e fontes de nitrogênio na recuperação de pastagens do capim-marandu. Arquivo Brasileiro de Medicina Veterinária e Zootecnia, 62(1), 192-199. https://doi.org/10.1590/S0102-09352010000100026

Da Silva, S. C., Sbrissia, A. F., \& Pereira, L. E. T. (2015). Ecophysiology of C4 forage grasses-understanding plant growth for optimising their use and management. Agriculture, 5(3), 598-625. https://doi.org/10.3390/agriculture5030598.

Epifanio, P. S., Costa, K. A. D. P., Severiano, E. D. C., Simon, G. A., \& Da Silva, V. R. (2019). Nitrogen nutrition and changes in the chemical attributes of the soil for cultivars of Brachiaria brizantha intercropped with Stylosanthes in different forage systems. Archives of Agronomy and Soil Science, 1, 1-16. https://doi.org/10.1080/03650340.2019.1658867

Euclides, V. P. B., Carpejani, G. C., Montagner, D. B., Nascimento Junior, D., Barbosa, R. A., \& Difante, G. S. (2017). Maintaining post-grazing sward height of Panicum maximum (cv. Mombaça) at $50 \mathrm{~cm}$ led to higher animal performance compared with post-grazing height of 
$30 \mathrm{~cm}$. Grass and forage science, 73(1), 174-182. https://doi.org/10.1111/gfs.12292

Fernandes, P. B., Barbosa, R. A., Morais, M. G., Medeiros-Neto, C., Fernandes, H. J., Gurgel, A. L. C., ... Silva, F. A. S. (2020). Tropical forage grasses intercropped under lenient grazing intensities promote greater soil cover. Journal of Agricultural Studies, 8(2), 213-223. https://doi.org/10.5296/jas.v8i2.16121

Ferreira, E. B., Cavalcanti, P. P., \& Nogueira, D. A. (2014). ExpDes: an R package for ANOVA and experimental designs. Applied Mathematics, 5(19), 2952. https://doi.org/10.4236/am.2014.519280

Gastal, F., \& Lemaire, G. (2015). Defoliation, shoot plasticity, sward structure and herbage utilization in pasture: review of the underlying ecophysiological processes. Agriculture, 5(4), 1146-1171. https://doi.org/10.3390/agriculture5041146

Gomide, C. A. D. M., \& Gomide, J. A. (2000). Análise de crescimento de cultivares de Panicum maximum Jacq. Revista Brasileira de Zootecnia, 28(4), 675-680. https://doi.org/10.1590/S1516-35981999000400003

Gomide, C. A., Paciullo, D. S., Morenz, M. J., Costa, I. A., \& Lanzoni, C. L. (2019). Productive and morphophysiological responses of Panicum maximum Jacq. cv. BRS Zuri to timing and doses of nitrogen application and defoliation intensity. Grassland Science, 65(2), 93-100. https://doi.org/10.1111/grs.12226

Gurgel, A. L. C., Difante, G. S., Montagner, D. B., Araujo, A. R., Dias, A. M., Santana, J. C. S., ... Pereira, M. G. (2020). Nitrogen fertilisation in tropical pastures: what are the impacts of this practice?. Australian Journal of Crop Science. 14(06), 978-984 https://doi.org/10.21475/ajcs.20.14.06.p2357

Lemaire, G., Da Silva, S. C., Agnusdei, M., Wade, M., \& Hodgson, J. (2009). Interactions between leaf lifespan and defoliation frequency in temperate and tropical pastures: a review. Grass and Forage Science, 64(4), 341-353 https://doi.org/10.1111/j.1365-2494.2009.00707.x

Li, P., Hao, X., Aryal, M., Thompson, M., \& Seneweera, S. (2019). Elevated carbon dioxide and nitrogen supply affect photosynthesis and nitrogen partitioning of two wheat varieties. $\begin{array}{llll}\text { Journal of Plant Nutrition, } & \text { 42(11-12), }\end{array}$ https://doi.org/10.1080/01904167.2019.1616758

Martins, C. D. M., Schmitt, D., Duchini, P. G., Miqueloto, T., \& Sbrissia, A. F. (2020). Defoliation intensity and leaf area index recovery in defoliated swards: implications for forage accumulation. Scientia Agricola, 78(2), e20190095. https://doi.org/10.1590/1678-992x-2019-0095

Menezes, B. B., Paiva, L. M., Fernandes, P. B., Campos, N. R. F., Barbosa, R. A., Bento, A. L. L., \& Morais, M. G. (2019). Tissue flow and biomass production of piatã grass in function of defoliation frequency and nitrogen fertilization. Colloquium Agrariae , 15(1), 92100. https://doi.org/10.5747/ca.2019.v15.n2.a288ca.

Oliveira, C. V. V. Barbosa, R. A., Oliveira, R. T., Almeida, E. M., Paludo, F., Lima, J. S. \& 


\section{Macrothink

Fernandes, P. B (2020). The tissue flow in Brachiaria brizantha pasture under intermittent stocking. Journal of Agricultural Studies , 8(1), 9- 17. https://doi.org/10.5296/jas.v8i1.15441

Oliveira-Neto, S. S., Gonçalves, A. S. F., Pietramale, R. T. R., \& Bellíssimo, M. J. (2020). Nitrogen and phosphate fertilization maximize grass BRS Zuri performance. Journal of Agricultural Studies, 8(1), 64-78. https://doi.org/10.5296/jas.v8i1.15521

Paciullo, D. S. C., Gomide, C. D. M., Castro, C. R. T., Maurício, R. M., Fernandes, P. B., \& Morenz, M. J. F. (2016). Morphogenesis, biomass and nutritive value of Panicum maximum under different shade levels and fertilizer nitrogen rates. Grass and Forage Science, 72(3), 590-600. https://doi.org/10.1111/gfs.12264

Rodrigues, C. S., Nascimento Júnior, D. D., Detmann, E., Da Silva, S. C., Sousa, B. M. D. L. \& Silveira M. C. T. D. (2012). Functional clusters of tropical forage grasses. Revista $\begin{array}{llll}\text { Brasileira de } \quad \text { Zootecnia, } & \text { 41(6), }\end{array}$ https://doi.org/10.1590/S1516-35982012000600010

Veras, E. L. L., Difante, G. S., Gurgel, A. L. C., Costa, A. B. G., Rodrigues, J. G., Costa, C. M., ... Costa, P. R. (2020a). Tillering and Structural Characteristics of Panicum Cultivars in the Brazilian Semiarid Region. Sustainability, v. 12(9), p. 3849, 2020. https://doi.org/10.3390/su12093849

Veras, E. L. L., Difante, G. S., Gurgel, A. L. C., Costa, C. M., Emerenciano Neto, J. V., Rodrigues, J. G., ... Ítavo, L. C. V. (2020b). Tillering Capacity of Brachiaria Cultivars in the Brazilian Semi-Arid Region During the Dry Season. Tropical Animal Science Journal, 43(2), 133-140. https://doi.org/10.5398/tasj.2020.43.2.133

\section{Copyright Disclaimer}

Copyright for this article is retained by the author(s), with first publication rights granted to the journal.

This is an open-access article distributed under the terms and conditions of the Creative Commons Attribution license (http://creativecommons.org/licenses/by/4.0/). 